\title{
FITOREMEDIASI ECENG GONDOK (Eichhornia crassipes) PADA LIMBAH DOMESTIK DAN TIMBAL DI HILIR SUNGAI BENGAWAN SOLO GRESIK SEBAGAI SOLUSI KETERSEDIAAN AIR BERSIH SEKARANG DAN MASA DEPAN
}

\author{
Phythoremidization of Water Hyacinth (Eichhornia crassipes) for \\ Domestic and Lead Waste in Bengawan Solo Gresik Downstream as \\ Solution to Clean Water Provision Now and Future
}

\author{
Ni'matul Zahro*, Varradiah Choirun Nisa' \\ Program Studi Pendidikan Kimia FMIPA Universitas Negeri Surabaya, \\ Jl. Lidah Wetan, Surabaya 60213, Jawa Timur, Indonesia \\ *email: nimatul.17030194057@mhs.unesa.ac.id
}

\begin{abstract}
Abstrak. Ketersediaan air bersih merupakan hal penting yang termuat dalam Sustainable Development Goals (SDGs) 2030. Pencemaran menjadi salah satu faktor rendahnya kualitas air bersih yang tersedia. Salah satu wilayah yang mengindikasikan adanya pencemaran air adalah hilir sungai bengawan solo di wilayah Gresik berdasarkan pengukuran kadar BOD, TDS, kandungan logam timbal, dan $\mathrm{pH}$. Fitoremediasi menjadi salah satu upaya untuk mengatasi pencemaran air dengan menggunakan Eceng gondok (Eichhornia crassipes). Berdasarkan kajian literasi, fitoremediasi menggunakan tanaman eceng gondok efektif untuk mereduksi limbah domestik dan $\mathrm{Pb}$. Fitoremediasi menggunakan tanaman eceng gondok memiliki efektivitas berupa penurunan BOD, TDS, $\mathrm{COD}$, TSS, penurunan kadar $\mathrm{Pb}$, dan dapat mengubah $\mathrm{pH}$. Teknologi fitoremediasi menggunakan tanaman eceng gondok berdampak positif terhadap kehidupan baik di masa sekarang dan masa mendatang.
\end{abstract}

Kata kunci: fitoremediasi, eceng gondok, kualitas air

\begin{abstract}
The availability of clean water is an important matter contained in the 2030 Sustainable Development Goals (SDGs). Pollution is one of the factors in the low quality of clean water available. One area that indicates water pollution is the downstream of the Bengawan Solo river in the Gresik region based on measurements of BOD, TDS, lead content, and $\mathrm{pH}$ levels. Phytoremediation is an effort to overcome water pollution by using water hyacinth (Eichhornia crassipes). Based on literacy studies, phytoremediation using water hyacinth is effective to reduce domestic waste and $\mathrm{Pb}$. Phytoremediation using water hyacinth plants has effectiveness in the form of reducing BOD, TDS, COD, TSS, decreasing Pb levels, and can change $\mathrm{pH}$. Phytoremediation technology using water hyacinth plants has a positive impact on life both now and in the future.
\end{abstract}

Keywords: phytoremidization, water hyacinth, water quality

\section{PENDAHULUAN}

Air merupakan kebutuhan hidup mutlak bagi manusia. Pentingnya ketersediaan air bersih bagi semua orang menjadi hal penting dan termuat dalam Sustainable Development Goals (SDGs) 2030. Tujuan SDGs 2030 yaitu memastikan ketersediaan dan manajemen air bersih yang berkelanjutan dan sanitasi bagi semua. Target-target dalam SDGs 2030 terkait dengan ketersediaan air bersih bagi semua antara lain tercapainya akses universal dan adil terhadap air minum yang aman dan terjangkau, akses sanitasi dan kebersihan yang layak dan adil. Namun, banyak daerah

Copyright $\odot$ JCAE-Jurnal Tugas Akhir Mahasiswa, e-ISSN 2613-9782

Program Studi Pendidikan Kimia FKIP Universitas Lambung Mangkurat 
di Indonesia masih mengalami krisis air bersih. Salah satu faktor utama yang menyebabkan Indonesia masih krisis air bersih adalah adanya pencemaran air. Hal ini memiliki dampak yang signifikan terhadap ketersediaan sumber air bersih yang layak untuk digunakan. Sungai di Indonesia yang kondisinya tercemar dan kritis mencapai 82 persen dari 550 sungai yang tersebar di seluruh Indonesia (Zuraya, 2019).

Kandungan limbah pencemar air dapat berupa bakteri maupun logam. Contoh pencemar logam adalah logam berat, fosfat, natrium, dan nitrogen. Sedangkan pencemar berupa bakteri contohnya bakteri fecal coliform dan bakteri patogen (Botkin \& Keller, 2011). Indikator kualitas air dapat diukur melalui kandungan bahan pencemar dengan kadar tertentu. Indikator kualitas air selain bahan pencemar adalah biological oxygen demand (BOD) dan dissolved oxygen (DO) (Cunningham \& Cunningham, 2011). BOD adalah jumlah oksigen yang digunakan oleh populasi mikroba untuk mendekomposisi bahan organik dalam jumlah tertentu dalam kondisi aerobik (Enger \& Bradley, 2009). DO adalah jumlah oksigen terlarut dalam air yang berasal dari fotosintesis dan absorbsi udara yang berfungsi mendukung kelangsungan hidup berbagai jenis organisme akuatik (Cunningham \& Cunningham, 2011). Indikator lain dapat berupa total dissolved solid (TDS) dan total suspended solid (TSS). TDS merupakan ukuran zat organik maupun anorganik yang terlarut pada suatu perairan (Agustira, Lubis, \& Jamilah, 2013). TSS merupakan padatan yang tersuspensi dalam air yang tertahan oleh saringan dengan ukuran partikel maksimal 2 $\mu \mathrm{m}$. Padatan ini terdiri atas lumpur, pasir halus, serta jasad-jasad renik yang disebabkan oleh kikisan tanah atau erosi yang masuk ke dalam perairan (Aleart, 1994). Indikator-indikator penentu kualitas air tersebut memiliki nilai yang berbedabeda dimana air dapat dikatakan tercemar atau tidak.

Air yang tercemar dapat dikurangi kadar bahan pencemarnya dengan salah satu teknik yang disebut dengan fitoremediasi. Fitoremediasi adalah metode untuk mengurangi, mendegradasi, atau mengisolasi bahan pencemar di lingkungan dengan menggunakan pengaplikasian tanaman dan mikroorganisme. Adanya penggunaan tanaman menjadikan teknik fitoremediasi lebih ramah lingkungan dan mampu menambah estetika serta murah dan mudah diterapkan (Moosavi \& Mohamd, 2013).

Salah satu tanaman yang dapat digunakan dalam proses fitoremediasi adalah Eichhornia crassipes (eceng gondok). Eceng gondok mampu tumbuh pada perairan tercemar dan mampu menghasilkan biomassa (Rai \& Singh, 2016). Berdasarkan penelitian yang telah dilakukan Dewi (2012) dapat disimpulkan bahwa eceng gondok mempunyai kemampuan menyerap unsur hara, senyawa organik dan kimia lain dari air limbah dalam jumlah besar. Dalam sebuah penelitian, wilayah dengan perlakuan penutupan $90 \%$ eceng gondok dapat menjadikan penurunan nilai BOD sampai 52\% dari nilai awal (Suradana, 2009). Eceng gondok memiliki toleransi terhadap Pb hinga taraf 55 ppm dan mampu mengakumulasi hingga 180 ppm Pb (Hidayati, Juhaeti, \& Syarif, 2008).

Berdasarkan uraian diatas, maka dapat disimpulkan bahwa solusi praktis dalam usaha peningkatan kualitas air guna mewujudkan Sustainable Development Goals (SDGs) 2030 adalah pengaplikasian metode fitoremediasi menggunakan tanaman eceng gondok. Artikel ini bertujuan untuk mengetahui efisiensi penggunaan tanaman eceng gondok (Eichhornia crassipes) untuk fitoremediasi hilir Sungai Bengawan Solo di Wilayah Gresik dan mengetahui dampak teknologi fitoremediasi dengan menggunakan tanaman eceng gondok (Eichhornia crassipes) terhadap kehidupan. 


\section{BAHASAN UTAMA}

\section{Pencemaran Logam Domestik dan Timbal di Hilir Sungai Bengawan Solo}

Dua permasalahan utama pada sumber daya air adalah rendahnya kuantitas dan kualitas. Kemajuan bidang industri menambah kompleksitas dari permasalahan sumber daya air. Bahan buangan dari industri baik berupa gas, padatan, maupun cairan dapat mengganggu keseimbangan lingkungan karena limbah pada umumnya tidak diolah terlebih dahulu sebelum dibuang ke lingkungan (Anna, 1991). Kualitas air adalah sifat air dan kandungan makhluk hidup, zat, energi, atau komponen lain di dalam air. Kualitas air dinyatakan dalam beberapa parameter yakni parameter fisika (kekeruhan, padatan, terlarut, suhu, dan sebagainya), parameter kimia (pH, BOD, kadar logam, oksigen terlarut, dan sebagainya), dan parameter biologi (keberadaan plankton, bakteri, dan sebagainya) (Pemerintah Republik Indonesia, 2001).

Bengawan Solo di wilayah Gresik dikategorikan sebagai air sungai kelas III yang menurut Perda No. 2 Tahun 2008 adalah lokasi budidaya perikanan dan tanaman. Aliran sungai Bengawan Solo dari wilayah hulu di Jawa Tengah melewati Sukoharjo dan Solo yang dikenal sebagai kawasan industri tekstil. Berdasarkan penelitian yang dilakukan oleh Daru Setyorini (Murdaningsih, 2020) untuk mengukur kualitas air dilihat dari parameter kimia yakni BOD (Biological Oxygen Demand), TDS (Total Dissolved Solid), kadar logam berat timbal, dan $\mathrm{pH}$ di Hilir Bengawan Solo yang diambil di tiga titik yakni jembatan Sembayat, Legowo, dan Tanjungsari diperoleh kadar BOD masing-masing 6,9 mg/L; $11 \mathrm{mg} / \mathrm{L}$; dan $11 \mathrm{mg} / \mathrm{L}$, kadar TDS masing-masing $1.436 \mathrm{mg} / \mathrm{L} ; 5.740 \mathrm{mg} / \mathrm{L}$; dan $5.200 \mathrm{mg} / \mathrm{L}$, kadar logam berat timbal masing-masing $0,42 \mathrm{mg} / \mathrm{L} ; 0,34 \mathrm{mg} / \mathrm{L} ; 0,43 \mathrm{mg} / \mathrm{L}$, nilai $\mathrm{pH}$ yang diperoleh sekitar 1 , 9, 8, dan 7. Menurut Peraturan Pemerintah Republik Indonesia Nomor 82 Tahun 2001 standar baku mutu kadar BOD pada sungai kelas III adalah 6 mg/L, kadar TDS 1.000 $\mathrm{mg} / \mathrm{L}$, kadar logam berat timbal adalah $0,03 \mathrm{~mL}$, dan $\mathrm{pH}$ sekitar 6-9. Dari pemaparan di atas, diperoleh bahwa kualitas air di hilir sungai Bengawan Solo di wilayah Gresik sudah tercemar. Kadar BOD, TDS, dan logam berat timbal melebihi nilai baku mutu standar di ketiga lokasi. Sedangkan nilai $\mathrm{pH}$, terdapat salah satu lokasi yang memiliki pH 1 yakni sangat asam.

Pencemaran air yang menyebabkan rendahnya kualitas air dapat diakibatkan oleh limbah hasil buangan industri salah satunya adalah industri tekstil. Limbah industri tekstil ini diduga berasal dari aliran wilayah Sukoharjo dan Solo di Jawa Tengah. Zat pewarna tekstil umumnya mengandung logam berat yang kandungannya di atas baku mutu yang telah ditetapkan oleh Peraturan Menteri Negara Lingkungan Hidup No. 3/MENLH/01/2010. Adapun beberapa logam berbahaya yang dominan terkandung dalam limbah tekstil adalah Tembaga $(\mathrm{Cu})$, Kromium $(\mathrm{Cr})$, dan Timbal $(\mathrm{Pb})$ (Suharty, 1999). Pada industri tekstil, logam timbal atau $\mathrm{Pb}$ digunakan sebagai campuran pewarna yakni warna putih dari timbal putih $\left[\mathrm{Pb}(\mathrm{OH})_{2} .2 \mathrm{PbCO}_{3}\right]$ dan warna merah dari timbah merah $\left(\mathrm{Pb}_{3} \mathrm{O}_{4}\right)$ (Latifah, et al., 2014). Logam timbal bersifat neurotoksin yang dapat terakumulasi dalam tubuh manusia dan hewan sehingga dapat membahayakan tubuh (Kusnoputranto, 2006).

\section{Peranan Fitoremediasi dalam Mengatasi Limbah}

Fitoremediasi adalah upaya penggunaan tanaman untuk pemulihan lingkungan berbagai jenis media yang tercemar kontaminan baik organik maupun anorganik. Adapun media yang dapat diremediasi dengan fitoremediasi adalah tanah, air tanah, dan air permukaan. Jenis kontaminan organik yang dapat diolah adalah senyawa hidrokarbon, pestisida, kondensasi gas, senyawa klor, dan senyawa mudah meledak. Sedangkan untuk kontaminan anorganik antara lain metaloid, salinitas, senyawa radioaktif, dan beberapa logam berat (Interstate Technology and Regulatory 
Coorperation, 2001).

Mekanisme fitoremediasi dalam mengurangi kontaminan dalam air limbah terdiri dari phytoextraction, phytostabilization, phytovolatilization dan rhizofiltration (Laghlimi, et al., 2015; Ansari, et al., 2015; (Muthusaravanan, et al.., 2018). Phytoextraction andalah penyerapan dan pemindahan kontaminan oleh akar tanaman dari lingkungan dan translokasi menjadi biomassa tanaman yang dapat dipanen (Laghlimi, et al., 2015; Ansari, et al., 2015). Phytostabilization adalah pengurangan mobilitas dan ketersediaan hayati polutan di lingkungan baik oleh efek fisik maupun kimiaseperti pengontrolan $\mathrm{pH}$ tanah, pengendapan, penyerapan, humifikasi dan lignifikasi senyawa organik (Laghlimi, et al., 2015; Ansari, et al., 2015). Phytovolatilization adalah proses penyerapan polutan oleh tanaman dan penguapan ke atmosfer oleh sistem daun (Laghlimi, et al., 2015). Rhizofiltration adalah penggunaan akar tanaman untuk menyerap atau mengadsorbsi kontaminan yang ada dalam larutan disekitar zona perakaran (Laghlimi, et al., 2015).

Faktor utama keberhasilan fitoremediasi ditentukan oleh pemilihan tumbuhan (Patra, Pradhan, \& Patra, 2020). Terdapat batas konsentrasi polutan yang dapat ditolerir oleh tanaman, menyebabkan teknik fitoremediasi biasanya menggunakan jenis-jenis tanaman yang toleran terhadap polutan tertentu. Tanaman dapat mati apabila konsentrasi polutan yang tinggi dan melebihi batas toleran. Tanaman secara umum hanya dapat hidup pada limbah dengan BOD kurang dari 300 $\mathrm{mg} / \mathrm{L}$ (Sumarsih, 2007).

\section{Eceng Gondok sebagai Agen Fitoremediasi}

Eceng gondok (Eichhornia crassipes) merupakan tanaman gulma di wilayah perairan yang hidup terapung pada air yang dalam yang memiliki aliran tenang.

$\begin{array}{ll}\text { Kingdom } & \text { : Plantae } \\ \text { Sub Kingdom } & \text { : Viridiplantae } \\ \text { Super Divisi } & : \text { Embryophyta } \\ \text { Divisi } & : \text { Tracheophyta } \\ \text { Kelas } & : \text { Magnoliopsida } \\ \text { Super Ordo } & : \text { Lilianae } \\ \text { Ordo } & : \text { Commelinales } \\ \text { Famili } & : \text { Pontederiaceae } \\ \text { Genus } & : \text { Eichhornia } \\ \text { Spesies } & : \text { Eichhornia Crassipes (Mart.) Solms }\end{array}$

Eceng gondok dapat tumbuh hingga tinggi sekitar 0,4 - 0,8 meter. Eceng gondok tidak memiliki batang sejati. Daunnya berwarna hijau, berbentuk daunnya oval, dan permukaannya licin. Dapat berbunga berwarna ungu dan termasuk bunga majemuk. Eceng gondok merupakan salah satu tanaman yang berakar serabut (Agrotek, 2020).

Badan Pengendalian Dampak Lingkungan Sumatera Utara (2003) menyatakan bahwa satu batang eceng gondok dalam waktu 52 hari dapat berkembang seluas $1 \mathrm{~m} 2$ dan dalam waktu satu tahun dapat berkembang seluas $7 \mathrm{~m} 2$. Eceng gondok mampu tumbuh pada perairan yang tercemar dan mampu menghasilkan biomassa (Rai \& Singh, 2016). Sitompul et al. (2013) menyatakan bahwa tanaman eceng gondok efektif untuk mengolah air limbah dengan waktu kontak 6 hari. Zat pencemar yang terkandung dalam air dapat diserap oleh Eceng gondok. Berdasarkan penelitian yang telah dilakukan Dewi (2012) dapat disimpulkan bahwa eceng gondok mempunyai kemampuan menyerap unsur hara, senyawa organik dan kimia lain dari air limbah dalam jumlah besar. Dalam sebuah penelitian, wilayah dengan perlakuan penutupan $90 \%$ eceng gondok dapat menjadikan penurunan nilai BOD sampai 52\% 
dari nilai awal (Suardana, 2009). Eceng gondok memiliki toleransi terhadap $\mathrm{Pb}$ hinga taraf 55 ppm dan mampu mengakumulasi hingga 180 ppm $\mathrm{Pb}$ (Hidayati, Juhaeti, \& Syarif, 2008).

\section{Ragam Metode Fitoremediasi}

Terdapat berbagai macam metode fitoremediasi yang dapat digunakan sebagai fitoremediasi, salah satunya adalah media Contructed Wetland (CW). Constructed Wetland merupakan metode pengolahan air limbah yang diadaptasi dari proses pengolahan air limbah secara alami oleh lahan basah dengan bantuan penting dari tumbuhan air (hidrofit) sebagai bentuk pemurnian diri (Hammer, 1986). Constructed Wetland didesain untuk mengambil keuntungan dari beberapa proses yang terjadi secara alami pada lahan basah tetapi dengan lingkungan yang lebih terkontrol. Metode ini memiliki beberapa kelebihan dalam proses pengolahan air limbah yaitu kemampuan menangani multi-polutan, biaya yang murah dan operasi yang mudah (Ansari, et al., 2015). Selain itu, metode Constructed Wetland juga memiliki konstruksi yang sederhana dan dapat disesuaikan dengan keadaan lapangan tempat pengolahan limbah, waktu yang cukup singkat akibat penambahan media dan tanaman yang sangat membantu mendegradasi polutan (Masfiyah, 2016).

Fitoremediasi dengan CW dapat diklasifikasikan berdasarkan jenis vegetasi, hidrologi dan arah arus (Vymazal, 2010). Berdasarkan pada hidrologi tanah yang digunakan, maka CW dibedakan menjadi free-water-surface (FWS) dan subsurface system dimana FWS lebih lanjut dikelompokkan berdasarkan arah arus menjadi horizontal subsurface flow dan vertical subsurface flow serta sistem hibrid dengan tujuan untuk mendapatkan performa yang lebih baik. Berikut beberapa tipe dari CW antara lain:

1. Free Water Surface Constructed Wetland (FWS CW)

Menurut Vymazal (2010), ciri-ciri FWS antara lain:

a. Merupakan baskom tertutup yang dangkal

b. Berisi 20-30 tanah perkaran dengan kedalaman air 20-40 cm

c. Kerapatan vegetasi berkisar $50 \%$

d. Memungkinkan tumbuhnya makrofit baik yang ditanam ataupun secara alami

e. Tanaman tidak dipanen dan berfungsi untuk menyediakan karbon organik untuk denitrifikasi

Media Free Water Surface Constructed Wetlands (FWS-CW) adalah pilihan yang baik untuk pengolahan air limbah karena biaya tidak membutuhkan biaya besar, energi yang dibutuhkan rendah, dan pemeliharaan yang mudah (Sitoresmi, 2015). FWS-CW dapat mendegradasi mikroba dan pengendapan partikel koloid untuk menghilangkan organik secara efisien. Partikel koloid yang telah mengendap dapat dihilangkan melalui penyaringan vegetasi yang lebat. Nitrogen dihilangkan terutama melalui nitrifikasi (dalam kolom air) dan denitrifikasi berikutnya (di lapisan serasah) dan penguapan amonia di bawah nilai $\mathrm{pH}$ yang lebih tinggi yang disebabkan oleh fotosintesis alga. Keunggulan dari tipe FWS yaitu tidak mudah tersumbat oleh kandungan TSS yang tinggi pada limbah domestik (Siswoyo, et al., 2020). Pada CW jenis ini, retensi fosfor biasanya rendah karena terbatasnya kontak air dengan partikel tanah yang menyerap dan / atau mengendapkan fosfor. Serapan tanaman hanya mewakili penyimpanan sementara karena nutrisi dilepaskan ke air setelah pembusukan tanaman (Ansari, et al., 2015).

2. Horizontal Subsurface Flow Constructed Wetland (HF CW)

Lahan basah yang dibangun dengan horizontal subsurface flow constructed 
wetland adalah saluran besar berisi kerikil dan pasir yang ditanami dengan vegetasi air. Ciri-ciri HF CW menurut Ansari et al. (2015) antara lain:

a. Air limbah mengalir secara horizontal melalui saluran

b. Tingkat air di lahan basah HF CW dipertahankan pada 5-15 cm di bawah permukaan.

c. Zona masuk yang lebar digunakan untuk mendistribusikan aliran secara merata

Perawatan awal sangat penting untuk mencegah penyumbatan dan memastikan perawatan yang efisien. Efisiensi penghilangan lahan basah yang dibangun tergantung pada luas permukaan dan luas penampang yang menentukan aliran maksimum yang mungkin. Sebuah saluran masuk yang dirancang dengan baik yang memungkinkan pemerataan penting untuk mencegah korsleting dan jalur preferensial. Saluran keluar harus bervariasi sehingga permukaan air dapat disesuaikan untuk mengoptimalkan kinerja pengolahan. Media filter berfungsi sebagai filter untuk menghilangkan padatan sekaligus sebagai alas tumbuh-tumbuhan. Bakteri fakultatif dan anaerobik dalam sistem mampu mendegradasi sebagian besar bahan organik. Vegetasi cenderung mentransfer sedikit oksigen ke zona perakaran sehingga bakteri aerob dapat berkoloni di area tersebut dan mendegradasi organik juga. Akar tanaman berperan penting dalam menjaga permeabilitas filter. Phragmites australis (buluh) seharusnya menjadi pilihan yang baik untuk $\mathrm{HF} \mathrm{CW}$, karena ia membentuk rimpang horizontal yang menembus seluruh kedalaman filter (Vymazal 2010). Dalam sistem ini, mekanisme penghilangan utama nitrogen adalah denitrifikasi, dan penghilangan amonia dibatasi karena kekurangan oksigen di tempat tidur filtrasi (Vymazal 2010). Fosfor dihilangkan terutama oleh reaksi pertukaran ligan, di mana fosfat menggantikan air atau hidroksil dari permukaan besi dan aluminium oksida hidro (Vymazal 2010).

3. Vertical Subsurface Flow Constructed Wetland (VF CW)

Tipe VF CW banyak digunakan untuk pengolahan limbah sekunder atau tersier (Ansari, et al., 2015). Air limbah disuplai dengan pompa atau perangkat sifon yang bekerja sendiri ke permukaan dan kemudian dialirkan secara vertikal ke bawah melalui lapisan filter menuju sistem drainase di bagian bawah. Ciriciri tipe VF CW menurut Ansari et al. (2015) antara lain:

a. Air limbah didistribusikan secara vertical

b. Terdapat sistem draine di bawah penyaring

c. Digunakan pasir dan kerikil sebagai bagian dari penyaring

d. Proses pengolahan dicirikan oleh interval pemuatan jangka pendek yang terputus-putus (4-12 dosis per hari) dan periode istirahat yang lama saat air limbah meresap melalui substrat tak jenuh dan permukaan mengering.

Pada VF CW, terdapat peningkatan transfer oksigen dan mengarah pada aktivitas degradasi aerobik yang tinggi, sehingga CW VF lebih aerobik daripada VF CW yang memberikan kondisi yang sesuai untuk nitrifikasi. Di sisi lain, VF CW tidak memberikan denitrifikasi (Vymazal 2010). VF CW mampu menghilangkan organik dan padatan tersuspensi secara efektif daripada $\mathrm{HF} \mathrm{CW}$. Selain itu, sistem VF CW membutuhkan lebih sedikit lahan dibandingkan dengan HF CW (Vymazal, 2010).

4. Hybrid Constructed Wetland

Hybrid constructed wetland adalah sistem yang direkayasa dengan tinggi yang dirancang dengan menggabungkan berbagai jenis lahan basah yang dibangun untuk mencapai efisiensi pengolahan yang lebih tinggi (Vymazal, 2010). Sistem hibrida paling sering terdiri dari lahan basah yang dibangun 
dengan aliran vertikal dan aliran horizontal yang diatur secara bertahap (Vymazal, 2010), dan sekarang digunakan di banyak negara di seluruh dunia. Sistem hibrida digunakan khususnya, ketika penghilangan amonia-N dan total $\mathrm{N}$ diperlukan (Vymazal, 2010). Sistem aliran horizontal tidak dapat menghasilkan nitrifikasi karena kapasitas transfer oksigennya terbatas. Sistem aliran vertikal dapat memberikan kondisi yang baik untuk nitrifikasi, tetapi denitrifikasi tidak benar-benar terjadi dalam sistem ini. Oleh karena itu, dalam sistem hibrid, keuntungan dari sistem aliran horizontal dan vertikal dapat digabungkan untuk melengkapi proses di setiap nitrifikasi dan sebagian denitrifikasi dan karenanya memiliki konsentrasi aliran keluar $\mathrm{N}$ total yang jauh lebih rendah (Vymazal, 2010).

Pengolahan limbah dalam constructed wetland berprinsip menguraikan limbah dalam bentuk Dissolved Inorganic Carbon (DIC), Particulate Organic Carbon (POC), Particulate Inorganic Carbon (PIC), Volatile Organic Carbon (VOC), dan Dissolved Organic Carbon (DOC) berlangsung secara aerobik. Hasil dari pengolahan bahan organik tersebut akan dimanfaatkan oleh fitoplankton dan tanaman air dengan demikian terjadilah pengurangan pencemar (U.S. Environmental Protection Agency, 1999)

Halverson (2004) menyatakan umumnya mekanisme penyerapan polutan pada constructed wetland dapat melalui proses abiotik yakni secara fisik dan kimia atau biotik melalui mikrobia dan tanaman atau gabungan dari keduanya. Adapun tahapan dalam proses abiotik yakni Settling dan sedimentasi, adsorpsi dan absorpsi, oksidasi dan reduksi, fotodegradasi, dan volatilisasi. Sedangkan proses biotik melalui penyerapan dan biodegradasi oleh tanaman.

\section{Efektivitas Eceng Gondok sebagai Agen Fitoremediasi Terhadap Limbah Domestik dan $\mathbf{P b}$}

Berdasarkan penelitian yang dilakukan oleh Nadhifah, et al. (2019), fitoremediasi menggunakan eceng gondok pada air limbah domestik setelah 12 hari perlakuan menunjukkan penurunan kadar BOD dari 7 ppm menjadi 1,6 ppm atau sekitar 77\% sedangkan kadar TDS dari 397,5 ppm menjadi 258 ppm atau sekitar $35 \%$. Penelitian lain yang dilakukan oleh Siswoyo, et al. (2020) menunjukkan bahwa eceng gondok memiliki kemampuan yang sangat baik dalam menurunkan pencemaran air limbah industri dimana mampu menurunkan kadar BOD, COD dan TSS masingmasing sebesar 97,9\%, 84,4\% dan 99,9\% menggunakan fitoremediasi tipe Constructed Wetlands. Penurunan BOD dan COD secara efektif juga terlihat pada penggunaan eceng gondok sebagai fitoremediasi pada limbah cair dimana penurunan BOD mencapai 52,12\% dan COD mencapai 70,83\% (Ningrum, Ghofar, \& Haeruddin, 2020). Fitoremediasi menggunakan Constructed Wetlands menggunakan tanaman eceng gondok (Eichhornia crassipes) mampu menurunkan kadar COD sebesar 63,7\% dan BOD sebesar 63,8\% (Masfiyah, 2016). Dari studi literatur yang telah dilakukan, dapat diketahui bahwa fitoremediasi menggunakan tanaman eceng gondok memiliki rata-rata efektivitas penurunan BOD sebesar 72,71\%, TDS sebesar 35\%, COD sebesar 73\%, dan TSS sebesar 99,9\%. Sehingga dapat disimpulkan bahwa fitoremediasi menggunakan tanaman eceng gondok efektif menurunkan BOD, TDS, COD, dan TSS.

Berdasarkan penelitian yang dilakukan oleh Aurangzeb, et al. (2014), penggunaan tanaman eceng gondok dalam fitroremidiasi air yang tercemar logam berat menunjukkan efisiensi yang sangat besar dimana salah satunya yaitu efisiensi penyerapan logam $\mathrm{Pb}$ sebesar $73 \%$. Penggunaan eceng gondok dengan menggunakan upflow reactors menunjukkan bahwa logam berat terakumulasi pada akar eceng 
gondok dan efiseiensi eceng gondok dalam menyerap logam berat $\mathrm{Pb}$ mencapai $98 \%$ (Soekomo, et al., 2012). Penelitian penyerapan logam berat dari air limbah menggunakan tanaman eceng gondok yang dilakukan oleh $\mathrm{Li}$, et al. (2015) menunjukkan bahwa laju penghilangan logam $\mathrm{Pb}$ dalam air oleh tanaman eceng gondok sebesar 98,33\%. Penelitian Fazal, et al. (2015) menunjukkan bahwa logam $\mathrm{Pb}$ mampu berkurang sebesar $83,4 \%$ pada kombinasi beberapa air limbah dengan fitoremediasi menggunakan eceng gondok. Dari studi literatur yang telah dilakukan, dapat diketahui bahwa fitoremediasi menggunakan tanaman eceng gondok memiliki rata-rata efisiensi penurunan $\mathrm{Pb}$ sebesar $88,18 \%$. Dengan demikian dapat disimpulkan bahwa fitoremediasi menggunakan tanaman eceng gondok efektif menurunkan kandungan $\mathrm{Pb}$ dalam air limbah.

Kualitas air hasil fitoremediasi menggunakan eceng gondok juga didukung dengan nilai $\mathrm{pH}$ yang sesuai dengan Peraturan Pemerintah Republik Indonesia No.82 tahun 2001 tentang Pengelolaan Kualitas Air dan Pengendalian Pencemaran Air yaitu berkisar 6-9. Penelitian yang dilakukan oleh Ningrum, Ghofar dan Haeruddin (2020) menunjukkan bahwa air hasil fitoremediasi menggunakan eceng gondok memiliki nilai $\mathrm{pH}$ berkisar 6,1-8,4. Fitoremediasi menggunakan eceng gondok menunjukkan bahwa setelah perlakuan selama 12 hari menunjukkan penurunan $\mathrm{pH}$ dari 8 menjadi 7 yang menunjukkan bahwa air hasil fitoremediasi menggunakan eceng gondok memiliki pH yang sesuai untuk dikonsumsi (Nadhifah, Fajarwati, \& Sulistiyowati, 2019). Penelitian lain yang dilakukan oleh Vidyawati dan Fitrihidajati (2019) menunjukkan peningkatan $\mathrm{pH}$ limbah domestik hasil fitoremediasi menggunakan eceng gongok yaitu dari 4,21 menjadi 7,34. Dari hasil penelitian yang telah diperoleh dari beberapa literatur menunjukkan bahwa fitoremediasi dengan eceng gondok mampu menyeseuaikan $\mathrm{pH}$ baik menaikkan ataupun menurunkan $\mathrm{pH}$ air menjadi berkisar 6-9 sesuai dengan Peraturan Pemerintah Republik Indonesia No.82 tahun 2001 tentang Pengelolaan Kualitas Air dan Pengendalian Pencemaran Air.

\section{Pengaruh Fitoremediasi untuk Masa Sekarang dan Masa Depan}

Air merupakan kebutuhan mutlak bagi semua makhluk hidup. Kehidupan berjalan dengan adanya ketersediaan air. Saat ini, kebutuhan dan konsumsi air bersih terus meningkat seiring dengan bertambahnya jumlah populasi manusia. Sayangnya, hal ini juga diikuti oleh semakin tingginya tingkat pencemaran air. Sungai di Indonesia yang kondisinya tercemar dan kritis mencapai $82 \%$ dari 55 sungai (Zuraya, 2019). Hal ini menimbulkan kebutuhan untuk mengelola kualitas air dengan mempertahankan tingkat aman untuk air sehingga bisa digunakan dalam kehidupan sehari-hari.

Pentingnya ketersediaan air bersih bagi semua orang menjadi hal penting dan termuat dalam Sustainable Development Goals (SDGs) 2030. Tujuan SDGs 2030 yaitu memastikan ketersediaan dan manajemen air bersih yang berkelanjutan dan sanitasi bagi semua. Target-target dalam SDGs 2030 terkait dengan ketersediaan air bersih bagi semua antara lain tercapainya akses yang adil dan universal pada air minum yang terjangkau serta aman dikonsumsi, akses sanitasi dan kebersihan yang layak dan adil. Perbaikan kualitas air dengan mengurangi polusi dan limbah, penggunaan air yang efisien dan tersedianya suplai air berkelanjutan, pengelolaan air terintegrasi, perlindungan dan perbaikan ekosistem air, dan sebagainya.

Air sangat penting dalam kehidupan semua makhluk hidup. Bagi manusiapun, ketersediaan air sangat diperlukan dalam berbagai aspek kehidupan. Teknologi fitoremediasi dengan model $\mathrm{CW}$ ini memberikan dampak positif terkait dengan ketersediaan air bersih. Dengan tenologi fiteoremidiasi yang dikembangkan, air tercemar dapat didaur ulang dan ditingkatkan kualitasnya sehingga dapat digunakan 
untuk kebutuhan semua orang. Hal ini dapat membantu mencapai ketersediaan dan manajemen air bersih yang berkelanjutan dan sanitasi bagi semua dan terwujudnya SDGs 2030.

\section{SIMPULAN}

Fitoremediasi adalah upaya pengunaan tumbuhan dan bagian-bagiannya untuk dekontaminasi limbah dan masalah-masalah pencemaran lingkungan. Tanaman eceng gondok (Eichhornia crassipes) dapat digunakan sebagai tumbuhan dalam teknologi fitoremediasi karena memiliki kemampuan untuk menyerap kontaminan. Berdasarkan kajian literasi, fitoremediasi menggunakan tanaman eceng gondok efektif untuk mereduksi limbah domestik dan $\mathrm{Pb}$. Fitoremediasi menggunakan tanaman eceng gondok dapat menurunkan kadar BOD, TDS, COD, TSS, kandungan Pb dalam air limbah, serta mampu menyeseuaikan $\mathrm{pH}$ baik menaikkan ataupun menurunkan $\mathrm{pH}$ air menjadi berkisar 6-9.

Teknologi fitoremediasi menggunakan tanaman eceng gondok (Eichhornia crassipes) berdampak positif terhadap kehidupan baik di masa sekarang dan masa mendatang karena mampu membantu mencapai ketersediaan dan manajemen air bersih yang berkelanjutan dan sanitasi bagi semua orang.

\section{DAFTAR RUJUKAN}

Agrotek. (2020). Klasifikasi dan Morfologi Tanaman Eceng Gondok. Dipetik Januari 12, 2021, dari agrotek.id: https://agrotek.id/klasifikasi-dan-morfologitanaman-eceng-gondok/

Agustira, R., Lubis, K. S., \& Jamilah. (2013). Kajian karekteristik kimia air, fisika air dan debit sungai pada kawasan DAS Padang akibat pembuangan limbah tapioka. Jurnal Online Agroteknologi.

Aleart, S. (1994). Metoda Penelitian Air. Surabaya: Penerbit Usaha Nasional.

Anna, A. N. (1991). Air Limbah Industri Permasalahan dan Penanggulangannya. Forum Geografi, 80, 50-51.

Ansari, A. A., Gill, S. S., Lanza, G. R., \& Newman, L. (2015). Phytoremidiation, Management of Enviromental Contaminanst (Vol. 2). New York: Springer International Publishing.

Aurangzeb, N., Nisa, S., Bibi, Y., Javed, F., \& Hussain, F. (2014). Phytoremidiation Potential of Aquatic Herbs from Steel Foundry Effluent. Brazilian Journal of Chemical Enginering, Vol. 31 (4): 881-886.

Botkin, D., \& Keller, E. A. (2011). Enviromental Science: Earth as a Living Planet. NJ: Willey.

Cunningham, W., \& Cunningham, M. (2011). Principles of Environmental Science. New York: McGraw-Hill Companies.

Dewi, Y. S. (2012). Efektivitas Jumlah Rumpun Tanaman Eceng Gondok (Eichhornia crassipes (Mart.) Solm) dalam Pengendalian Limbah Cair Domestik. Jurnal Teknik Lingkungan, 2 (13), 151-158.

Enger, E., \& Bradley, F. S. (2009). Enviromental Science A Study of Interrelationships. New York: McGraw-Hill Companies.

Fazal, S., Zhang, B., \& Mehmood, Q. (2015). Biological Treatment of Combined Industrial Wasterwater. Ecologycal Enginering, 551-558.

Halverson, N. V. (2004). Review of Constructed Subsurface Flow vs. Surface Flow Wetlands. Springfield: U.S. Department of Energy.

Hammer, M. (1986). Water and Wastewater Technology SI Version. Singapore: John Willey and Sons. 
Hidayati, N., Juhaeti, T., \& Syarif, F. (2008). Potensi Hiperakumulator Saccharum spontaneum pada Limbah Tailing Terkontaminasi Sianida. Biota: Jurnal Imiah Ilmu-Ilmu Hayati, 13(2), 115-124.

Interstate Technology and Regulatory Coorperation. (2001). Phytotechnology Technical and Regulatory Guidance Document. Washington DC: ITRC.

Kusnoputranto, H. (2006). Toksikologi Lingkungan: Logam Toksik dan Berbahaya. Jakarta: FKM-UI Press.

Laghlimi, M., Baghdad, B., Hadi, H., \& Bouabdli, A. (2015). Phytoremediation Mechanism of Heavy Metal Contamineted Soild: A Review. Journal of Ecology, 5, 375-388.

Latifah, R. (2014). Pemanfaatan $\alpha$-Keratin Bulu Ayam Sebagai Adsorben Ion Timbal $(\mathrm{Pb})$. ALCHEMY Jurnal Penelitian Kimia, 10(1), 11-21.

Li, Q., Chen, B., Zhou, J., Zhan, J., Lin, P., Shen, Q., \& Pan, X. (2015). Adsorption of Heavy Metal from Aqueous Solution by Dehydrated Root Powder of LongRoot Eichhornia crassipes. International Journal of Phytoremediation, Vol.18: 103-109.

Masfiyah. (2016). Kajian Sistem Constructed Wetland Menggunakan Eceng Gondok Pada Penanganan Limbah Cair Pengolahan Kopi. Skripsi. Jember: Teknik Pertanian Universitas Jember.

Moosavi, S., \& Mohamd, J. S. (2013). Phytoremediation: A Review. Journal Advance in Agriculture and Biology, Vol.18: 103-109.

Murdaningsih, D. (2020, September 21). Hilir Sungai Bengawan Solo Diduga Tercemar Logam Berat. Dipetik Desember 23, 2020, dari Republika.co.id: https://republika.co.id/berita/qh0037368/hilir-sungai-bengawan-solo-didugatercemar-logam-berat

Muthusaravanan, S., Sivarajasekar, N., Vivek, J., Paramasivan, T., Naushad, M., \& Prakashamaran, J. (2018). Phytoremidiation of heavy metals: mechanism, methods, and enhancements. Berlin: Springer International Publishing.

Nadhifah, I., Fajarwati, P., \& Sulistiyowati, E. (2019). Fitoremidiase dengan Wetland System Menggunakan Eceng Gondok (Eichhornia crassipes), Genjer (Limnocharus flava), dan Semanggi (Morsilea crenata) untuk Mengolah Limbah Domestik. Journal of Biology, Vol.1291): 38-45.

Ningrum, Y. D., Ghofar, A., \& Haeruddin. (2020). Efektivitas Eceng Gondok (Eichhornia crassipes) sebagai Fitoremidiator pada Limbah Cair Produksi Tahu. Journal of Maquares, Vol.9(2): 97-106.

Patra, D., Pradhan, C., \& Patra, H. (2020). Toxic metal decontamination by phytoremediation approach: Concept, challenges, opportunities and future perspectives. Environmental Technology \& Innovation, 18, 1-7. doi:10.1016/j.eti.2020.100672

Pemerintah Republik Indonesia. (2001). Peraturan Pemerintah Nomor 82 Tahun 2001 tentang Pengelolaan Kualitas Air dan Pengendalian Pencemaran Air. Jakarta: Presiden Republik Indonesia.

Rai, P. K., \& Singh, M. M. (2016). Eichhornia crassipes as a Potential Phytoremediation Agent and An Important Biosource for Asia Pacific Region. Article of Enviromental Skpetics and Critics, 5(1), 12-19.

Siswoyo, E., Faisal, Kumalasari, N., \& Kasam. (2020). Contructed Wetlands dengan Tumbuhan Eceng Gondok (Eichhornia crassipes) Sebagai Alternatif Pengolahan Air Limbah Industri Tapioka. Artivle of Enviromental Skeptics ad Critics, 5(1), 12-19. 
Sitompul, D. F., Mumu, S., \& Kancitra, P. (2013). Pengolahan limbah cair Hotel Aston Braga City Walk dengan proses fitoremediasi menggunakan tumbuhan eceng gondok. Jurnal Institut Teknologi Nasional, 1(2), 105-114.

Sitoresmi, P. W. (2015). Pemanfaatan Constructed Wetland dengan Tanaman Papirus (Cyperus papyrus) untuk Pengolahan Surfaktan dalam Air Limbah Laundry. Surabaya: Jurusan Teknik Lingkungan ITS.

Soekomo, C., Vedaste, K., Diederik, R., \& Piet, L. (2012). Heavy Metal Remover by Combining Anaerobic Upflow Packed Bed Reactors with Hyacinth Ponds. Enviromental Technology, Vol.33 (12): 1455-1464.

Suardana, I. W. (2009). Pemanfaatan Eceng Gondok (Eichhornia crassipes (Mart) Solm) sebagai Teknik Alternatif dalam Pengolahan Biologis Air Limbah Asal Rumah Pemotongan Hewan (RPH) Pesanggran Denpasar-Bali. Berita Biologi, 9(6), 759-766.

Suharty, N. S. (1999). Studi Kualitas Fisik Kimia 3 (Tiga) Anak Sungai Bengawan Solo di Kabupaten Karanganyar. Surakarta: Pusat Studi Lingkungan Hidup Lembaga Penelitian Surakarta.

Sumarsih, S. (2007). Fitoremediasi. Rekayasa Bioproses. Yogyakarta: Teknik Lingkungan UPNVY.

Suradana, I. W. (2009). Pemanfaatan Eceng Gondok (Eichhornia crassipes (Mart) Solm) sebagai Teknik Alternatif falam Pengolahan Biologis Air Limbah Asal Rumah Pemotongan Hewan (RPH) Pesanggran Denpasar-Bali. Berita Biologi, 9(6), 759-766.

U.S. Environmental Protection Agency. (1999). Draft Guidance for Water Quality. Washington DC: Office of Water - EPA.

Vidyawati, D. S., \& Fitrihidajati, H. (2019). Pengaruh Fitoremidiasi Eceng Gondok (Eichhornia crasspies) Melalui Pengenceran Terhadap Kualitas Cair Industri Tahu. Lentera Bio, Vol.8(2): 530-549.

Vymazal, J. (2010). Constructed Wetlands for Wastewater Treatment. Water, Vol (2): 530-549.

Zuraya, N. (2019, Maret 23). 82 Persen Sungai di Indonesia Tercemar dan Kritis. Dipetik November 23, 2020, dari Republika.co.id.: http://nasional.republika.co.id/berita/nasional/umum/porsc1383/82-persensungai-di-indonesia-tercemar-dan-kritis 